\title{
WASHING WATER TURBIDITY AS INDICATOR TO FRUIT AND VEGETABLE WASHER EFFICIENCY
}

\author{
H.S. AI-Katary ${ }^{1}$, \\ H.A. Abd El-Mawla ${ }^{2}$, \\ M.A. Osman ${ }^{3}$ \\ and A.M. Ahmed ${ }^{4}$
}

ABSTRACT

The main goal of the present investigation was to study of using washing water turbidity to measure transparency of the water as a parameter that indicate vegetable and fruit washing efficiency. Turbidity can measure by turbidity measuring device to improve the quality of the process with low complexity. Laboratory tests of the operation have yielded satisfactory repeatability and stability. Washing productivity of the washing machine, washing efficiency of the washing machine, Analysis of Water (turbidity) and fruit damage percentage were resulted.

Keywords: turbidity, washable, quality.

\section{INTRODUCTION}

$\mathrm{H}$ arvested crops usually contain some of unwanted material such as leaves, twigs, stems, soil, and residues of pesticides. Removal of these unwanted materials as early as possible after harvest is important in order to avoid: crop contamination from bacteria, fungi, soil, and residues of pesticides, damage to the crop (like stick punctures in fruit). Additional heats build up in the crop from respiration of unwanted material, improve product appearance and edibility, Remove residues of field-applied and harmful chemicals, Microorganisms those would shorten the life of the product. Abd El Rahman (1999).

Many crops must be cleaned after they are harvested to improve product appearance and edibility to remove residues of field-applied chemicals and to remove harmful microorganisms that would shorten the life of the product. Hassan (1988) and Hossain et al., (1991).

Papadopoulou et al., (1998) mention that the clarity of the water which

\footnotetext{
${ }^{1}$ Prof. of Agric. Eng., Agric. Eng. Dept., Fac. of Agric., Al-Azhar Univ., Nasr city.

${ }^{2}$ Prof. and Head of Agric. Eng. Dept., Fac. of Agric., Al-Azhar Univ., Assiut.

${ }^{3}$ Prof. of Food Sci. and Tech., Dept., Al-Azhar Univ., Nasr city.

${ }^{4}$ Demonstrator, Agric. Eng. Dept., Fac. of Agric., Al-Azhar Univ., Assiut.
} 
is affected by the concentration of suspended particles is a measure of its quality.

Drinking water should have a turbidity of $\leq 5$ NTU Davis et al., (2002). The WHO (2004). (World Health Organization), established the turbidity of drinking water should not be more than 5 NTU (Nephelometric Turbidity Units), and should ideally be below 1 NTU.

Turbidity is an expression of the optical property of a medium, which causes light to be scattered and absorbed rather than transmitted straight through a sample. The medium concerned is usually water in which light is scattered by suspended particles. Turbidity is defined by the International Standards Organization (ISO) as the "reduction of transparency of a liquid caused by the presence of undissolved matter". It is measured using the techniques of turbidimetry or nephelometry and is expressed in arbitrary units NTU (Nephelometric Turbidity Units). The direct relationship between turbidity data and suspended solids concentration depends on many factors, including particle size distribution, particle shape and surface condition, refractive index of the scattering particles and of the suspension medium and wavelength of the light. Lawler (1995).

The washing efficiency was calculated by Scott et al., (1981).

$\mathrm{WE}=(\mathrm{SR} / \mathrm{SA}) \times 100, \%$. Where: $\mathrm{WE}=$ Washing efficiency, $\%$.

$\mathrm{SR}=$ Mass of foreign materials removed by washing $=$ Mass of sample before washing - mass of sample after washing, $\mathrm{g} / \mathrm{kg}$.

$\mathrm{SA}=$ Mass of foreign material attached, which was estimated by, hand washing of 30 samples of fruits to full cleaning and weighing the foreign materials attached with one $\mathrm{kg}$ of fruits $(\mathrm{g} / \mathrm{kg})$.

The aim of this study is to using a turbidity for indicate quality of some vegetables and fruits that be washed in the washing machine.

\section{MATERIAL AND METHODES}

\section{Material:}

\section{Tested vegetable and fruit:}

The tested-fruits types were Navel orange and Nicola potatoes.

\section{Designed washing machine.}

The designed washing-machine consists of the following parts 


\subsection{Frame.}

The frame consists of $1 \mathrm{Inch}(2.54 \mathrm{~cm})$ iron angles with $200 \mathrm{~cm}$ length, 50 $\mathrm{cm}$ width and $100 \mathrm{~cm}$ height.

\subsection{Fruit hopper.}

The hopper was made of galvanized-steal sheet. with $70 \mathrm{~cm}$ length, $90 \mathrm{~cm}$ width in top, and $20 \mathrm{~cm}$ length and $30 \mathrm{~cm}$ in bottom. The hopper height is $50 \mathrm{~cm}$. The capacity of fruit hopper is about $92.5 \mathrm{~kg}$ orange fruits and about $77 \mathrm{~kg}$ potatoes. Fruit hopper was designed according to mechanical and physical proprieties of fruits fig. 1.

The brush was made of 4-inch PVC pipe. With $150 \mathrm{~cm}$ length, the brush consists of plastic wisps with about 100 hairs. The wisps are fixed on 4 inches PVC pipe by about $2.5 \mathrm{~cm}$ plastic tubes which interfered with PVC pipe by about $3 \mathrm{~cm}$ screw bolt. The wisps fixed around PVC pipe have auger shape.

\subsection{Electrical motor.}

The specifications of electrical motor are $0.4 \mathrm{~kW}$ power, $1400 \mathrm{rpm}$.

\subsection{Power transmission.}

Power transmission consists of gearbox, pulleys and V belt. Motored pulleys of $4 \mathrm{~cm}$ diameter transmits the power to $15,11.2$ or $9 \mathrm{~cm}$ diameter, gear box pulleys to give speeds of 357, 500, 625 or rpm. The gearbox reduction ratio is $1 / 12.5$ to give pipe brush speed 30,40 or 50 rpm.

\subsection{Washing basin.}

The washing basin was made of galvanized sheet steel with $150 \mathrm{~cm}$ length, $50 \mathrm{~cm}$ width and $25 \mathrm{~cm}$ depth with three sides $20 \mathrm{~cm}$ length $\times 150$ cm long.

\subsection{Drainage water basin.}

Drainage water basin also made of galvanized steel sheet with $150 \mathrm{~cm}$ length and $50 \mathrm{~cm}$ width fabricated as a half of circle with $25 \mathrm{~cm}$ of radius and capacity about $0.147 \mathrm{~m}^{3}(\approx 145$ liter $)$ of water.

\subsection{Sponge drying sheet.}

The drying sheet was made of sponge sheet with $50 \mathrm{~cm}$ width and $50 \mathrm{~cm}$ length. 


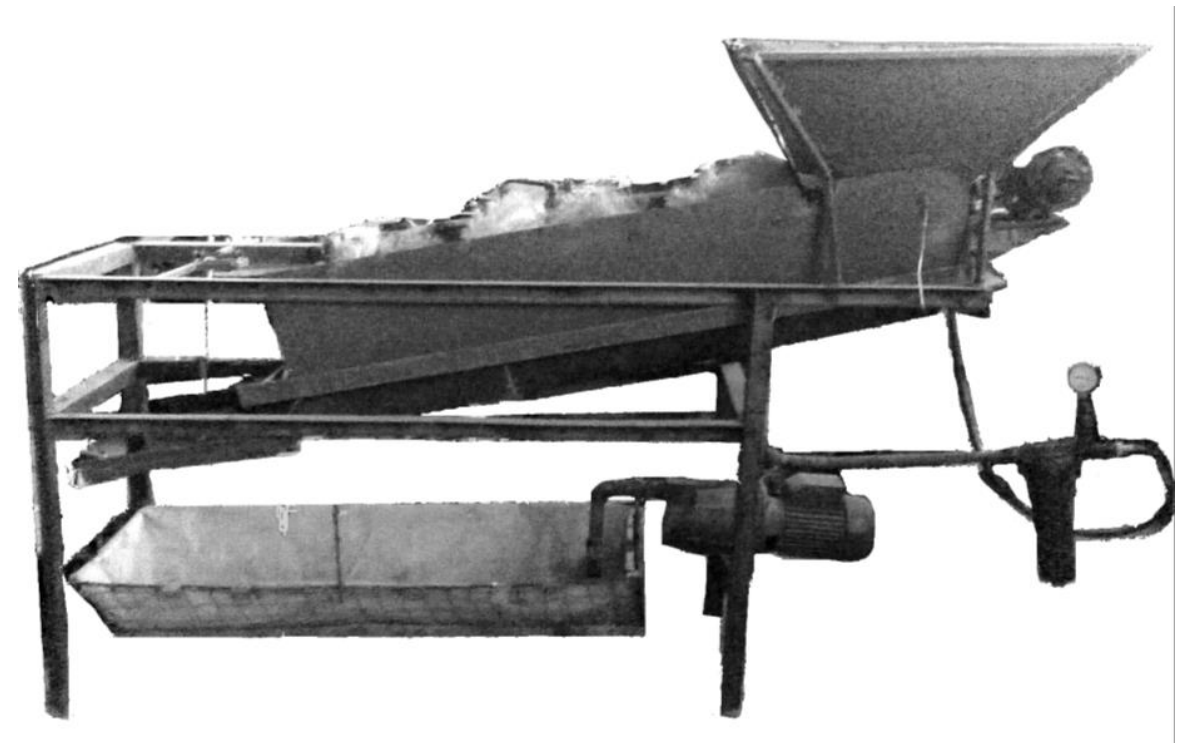

Plat 1: Elevation feature of the washing machine.
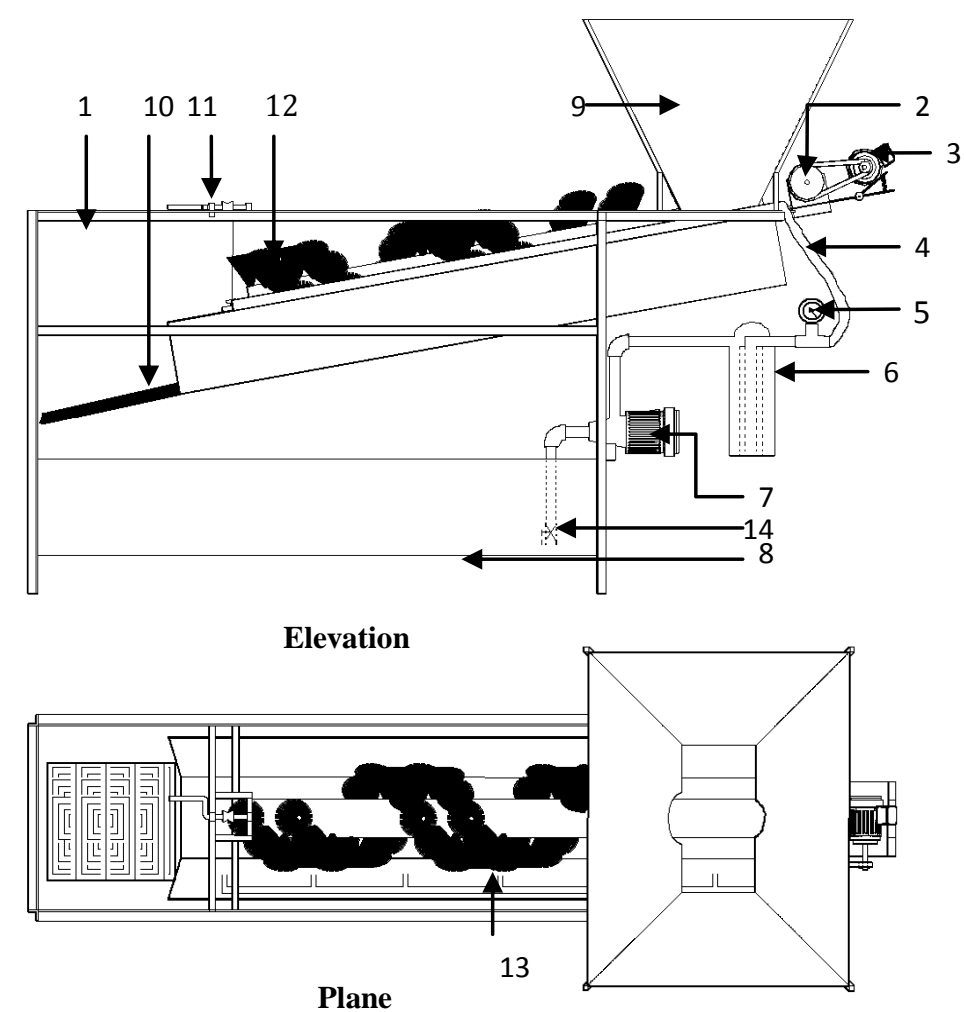

1- main frame

2- Gear box

3- Motion motor

4- Water proboscis

5- Pressure gage

6- Filter

7- Pump

8- Drain basin

9- The Hoper

10- Dryer sheet

11- Angels changer device

12- Washing brush

13- Water outlet

14- Valve

Fig. 1: Schematic diagram of washing machine.

2.3. Washing brush.

Misr J. Ag. Eng., April 2010 


\subsection{Filter.}

The Filter was made of cylindrical of fiberglass with $15 \mathrm{~cm}$ diameter, 30 $\mathrm{cm}$ height and 10 bars maximum pressure.

\subsection{Pump.}

A centrifugal pump of $1.5 \mathrm{hp}(1.1 \mathrm{~kW}), 1 \mathrm{ph}$, and $230 \mathrm{~V}$. was used.

\section{Instruments:}

\subsection{Electronic balances.}

An electronic Korean balance model THP-600 TAYO Company with accuracy is $0.01 \mathrm{~g}$ and maximum scale of $600 \mathrm{~g}$ was used to measure fruits sample mass.

\subsection{Turbidity measuring device.}

The Turbidity measuring device Japan Model. HORIBA with High sensitive turbidity sensor ranged between 0 and 1,000 NTUs (Nephelometric Turbidity Units) was used to check water quality.

\subsection{Stop watch and caliper.}

Stopwatch and caliper were used to record the time spend in washing operation and masseur different dimensions.

\section{Operation theory of designed washing machine.}

The system of washing represented in the product brushed and displaced by the moving brush until arriving to dryer sheet. The discharged out, so the foreign materials are removed from the surface of the product or dissolving in discharged water.

The water discharged after washing through the filter that removes the suspended materials from the water. The cleaned water pumped to the washing machine outlets.

\section{Methods:}

\section{Productivity of the washing machine.}

The washing Productivity was calculated according to Amin (1995) by the following equation:

$\mathrm{C}=\mathrm{M} \times 60 / \mathrm{T}_{\mathrm{w}}$,

Where:

$\mathrm{C}=$ Washing capacity of the machine (Ton $/ \mathrm{h}$ ).

$\mathrm{M}=$ Mass of the washed fruit, (Ton).

$\mathrm{T}_{\mathrm{W}}=$ Washing time, (min). 
2. Efficiency of the washing machine by using Turbidity measuring device.

$\mathrm{WE}=(\mathrm{T} / \mathrm{t}) \times 100, \%$.

Where:

$\mathrm{T}=$ Turbidity ratio in water after washing by machine, NTU for $1 \mathrm{Kg}$ fruit/ 1 liter pure water

$\mathrm{t}=$ Turbidity ratio in water after washing by hand, NTU for $1 \mathrm{Kg}$ fruit/ 1 liter pure water.

\section{Analysis of turbidity.}

After completion of washing process samples of the dirty water was collected from the 1 liter per $1 \mathrm{~kg}$ vegetables or fruits that washed by machine and comber it with sample of 1 liter per $1 \mathrm{~kg}$ vegetables or fruits that washed by hand.

\section{Fruit damage percentage.}

To determine the surface injuries in fruits, the sample was taken and deluged in a staining solution ( $2 \%$ Gentian violet) for five minutes, the surface injures reading will be visible.

In table 1 Mechanical injury can be classified according to Kader (1992) into the following categories.

Table 1: Categories of fruits mechanical injury (Kader, 1992.)

\begin{tabular}{|c|c|c|}
\hline No. & Injurv Categories & No. of fruits iniured, $\%$ \\
\hline 1 & No symptoms & 0 \\
\hline 2 & Slight & $<2$ \\
\hline 3 & Moderate & $2-5$ \\
\hline 4 & Severe & $5-10$ \\
\hline 5 & Extreme & $>10$ \\
\hline
\end{tabular}

\section{RESULTS AND DESCUSSION}

The operating tests of the turbidity measuring device on the washable product quality indicated that:

\section{Productivity of the washing machine.}

The productivity of the washing machine was calculated. It can be noticed that 1.35 ton / $\mathrm{h}$ was the best productivity with $10 \mathrm{~kg} / \mathrm{min}$ feeding rate, $15^{\circ}$ washing basin and $40 \mathrm{rpm}$. Brush speeds to the Navel orange. 
Moreover, 1.24 ton / $\mathrm{h}$ was the best productivity in the lowest standard error with $10 \mathrm{~kg} / \mathrm{min}$ feeding rate, $15^{\circ}$ washing basin and $50 \mathrm{rpm}$. brush speeds to the Nicola potatoes. As shown in Fig. 2 to Navel orange and Fig. 3 to Nicola potatoes.

\section{Washing efficiency of the washing machine.}

The Washing efficiency of the washing machine was calculated. It can be noticed that $90 \%$ was the best efficiency with $5 \mathrm{~kg} / \mathrm{min}$ feeding rate, 10 degree washing basin and $40 \mathrm{rpm}$. brush speeds to Navel orange. In addition, $92.4 \%$ was the best efficiency in the lowest standard error with $10 \mathrm{~kg} / \mathrm{min}$ feeding rate, 5 degree washing basin and $30 \mathrm{rpm}$. brush speeds to Nicola potatoes. As shown in Fig. 4 to Navel orange and Fig. 5 to Nicola potatoes.

\section{Analysis of turbidity.}

The results of the water turbidity were presented in fig. 6 of $1 \mathrm{Kg}$ fruit/ 1 liter pure water $=224$ NTUs to Navel orange. Moreover, the results of the water turbidity were presented in fig. 7 of $1 \mathrm{Kg}$ fruit/ 1 liter pure water $=$ 731 NTUs to Nicola potatoes.

\section{Fruit damage percentage.}

The best parameters to get the lowest fruit damage percentage of the washing machine affected by the feeding rate of the fruits, angles of washing basin, and speeds of brush. It can be noticed that $0.05 \%$ was the lowest fruit damage percentage (Slight) with $5 \mathrm{~kg} / \mathrm{min}$ feeding rate, 15 degree washing basin and $50 \mathrm{rpm}$. brush speeds to Navel orange. In addition, $0 \%$ was the lowest fruit damage percentage (No symptoms) with $5 \mathrm{~kg} / \mathrm{min}$ feeding rate, 15 degree washing basin and $40 \mathrm{rpm}$. brush speeds to Nicola potatoes. As shown in Fig. 8 to Navel orange and Fig. 9 to Nicola potatoes. 
PROCESS ENGINEERING
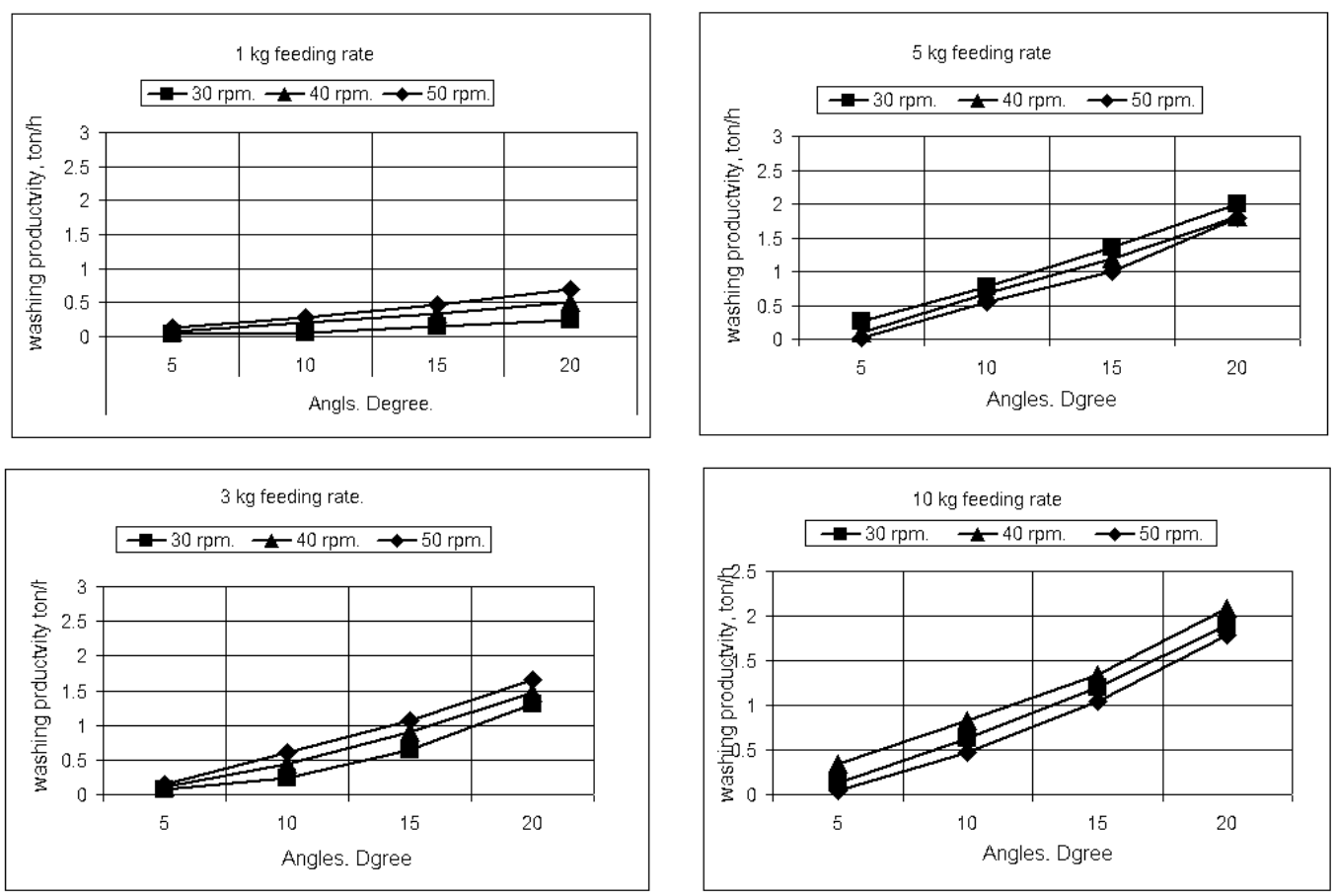

Fig. 2: Effect of brush speeds on washing productivity of Navel orange at different feeding rates and different angles.
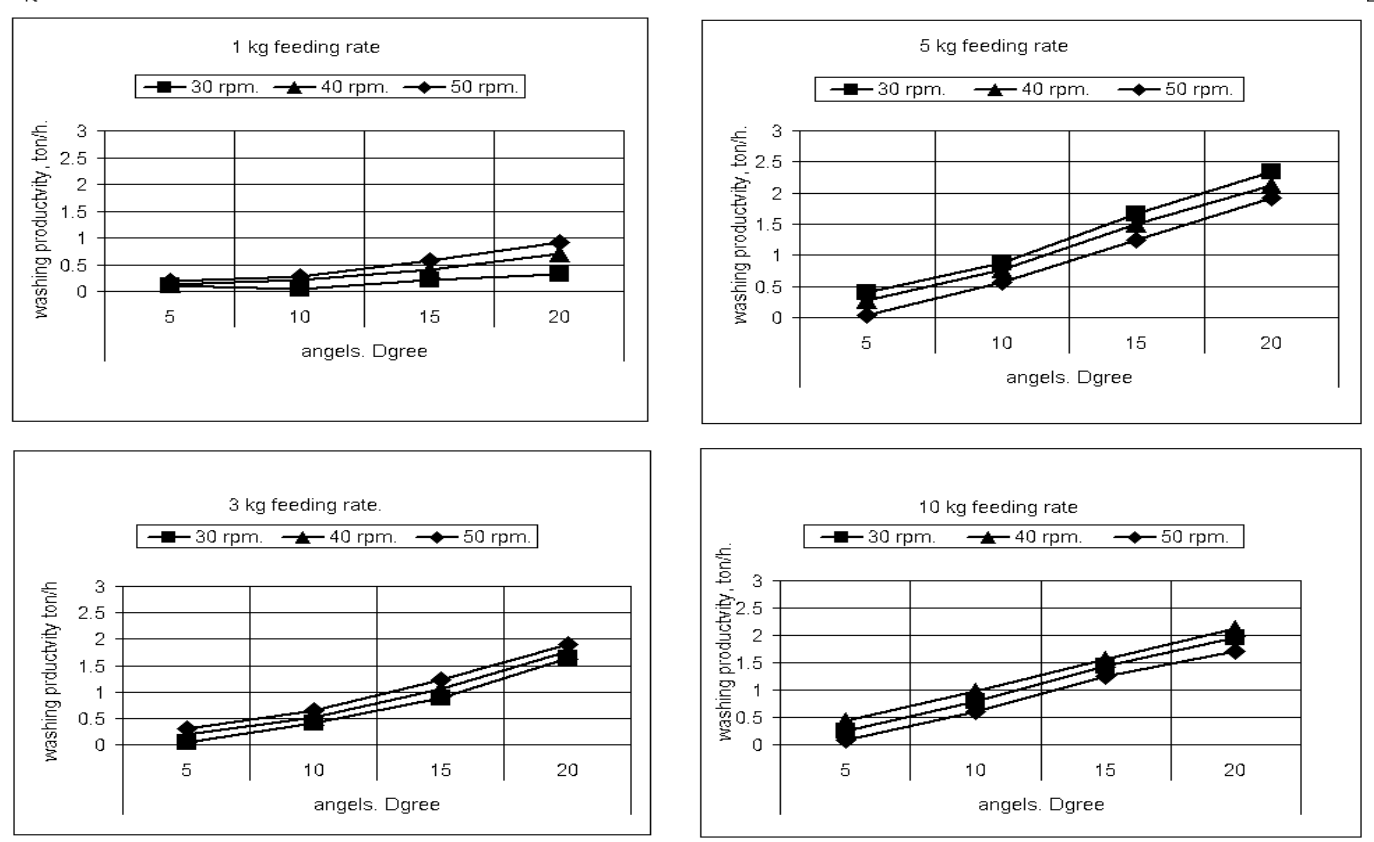

Fig. 3: Effect of brush speeds on washing productivity of Nicola potatoes at different feeding rates and different angles. 
PROCESS ENGINEERING
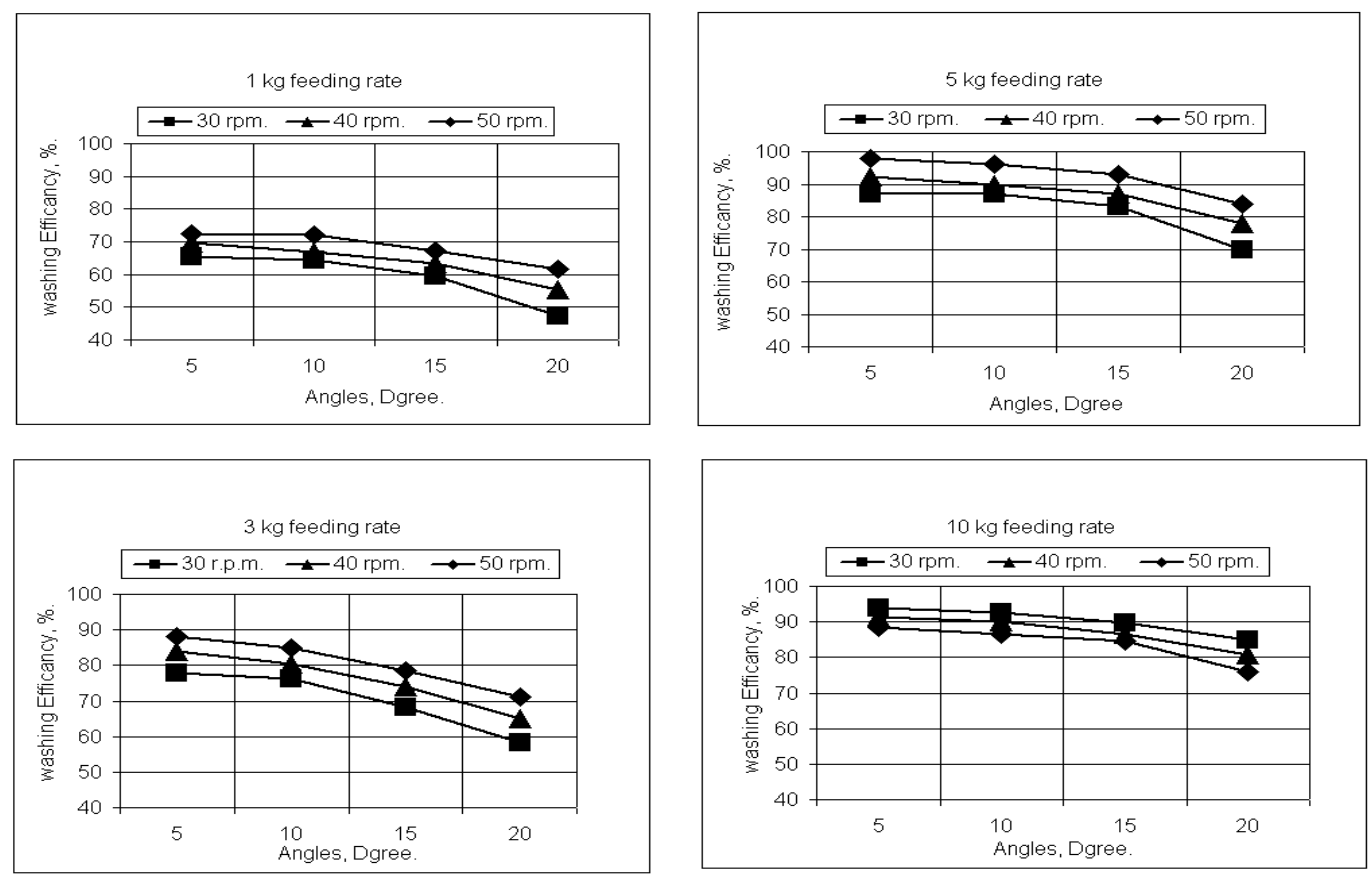

Fig. 4: Effect of brush speeds on washing Efficiency of Navel orange at different feeding rates and different angles.
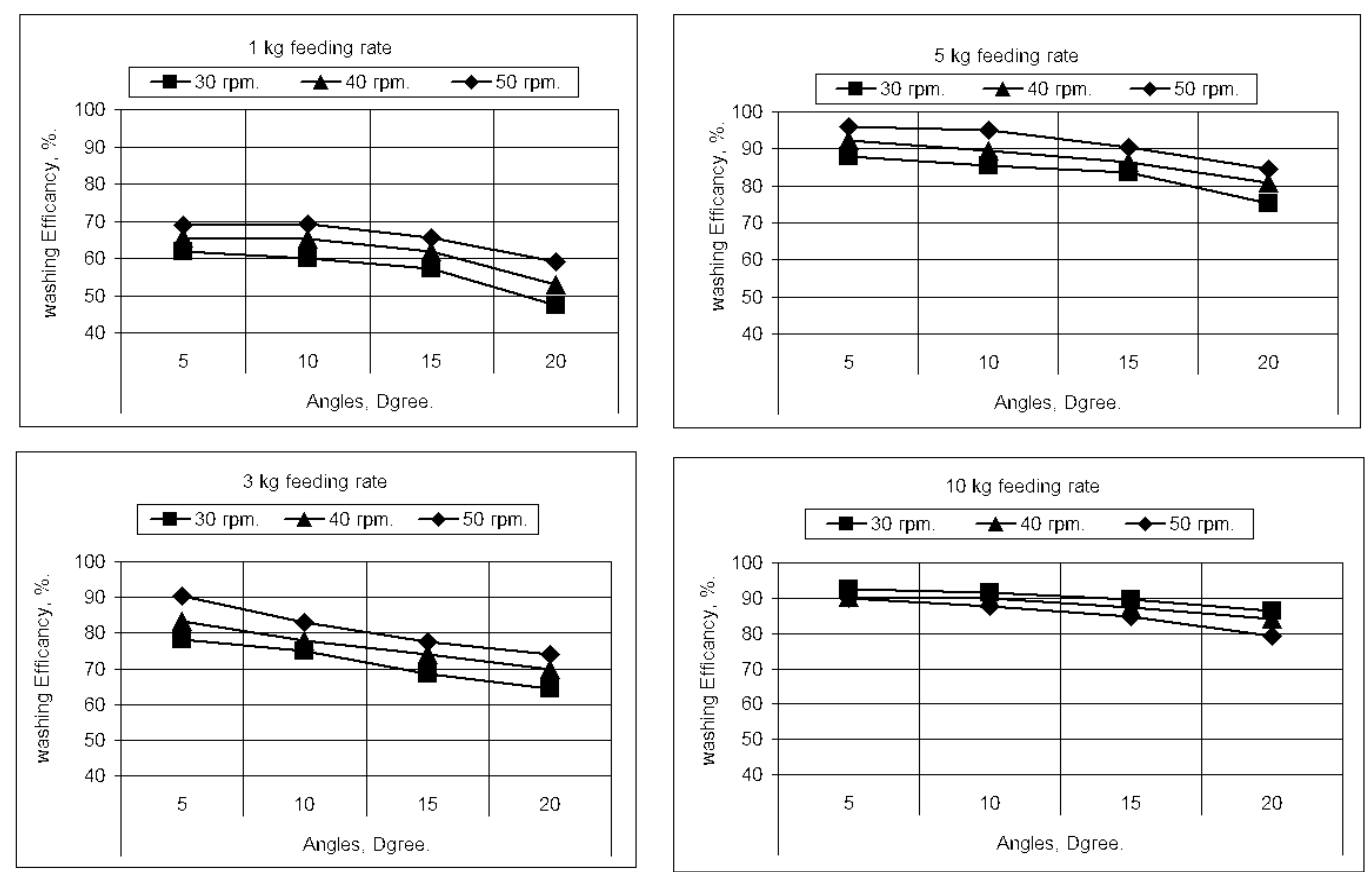

Fig. 5: Effect of brush speeds on washing Efficiency of Nicola potatoes at different feeding rates and different angles. 
PROCESS ENGINEERING
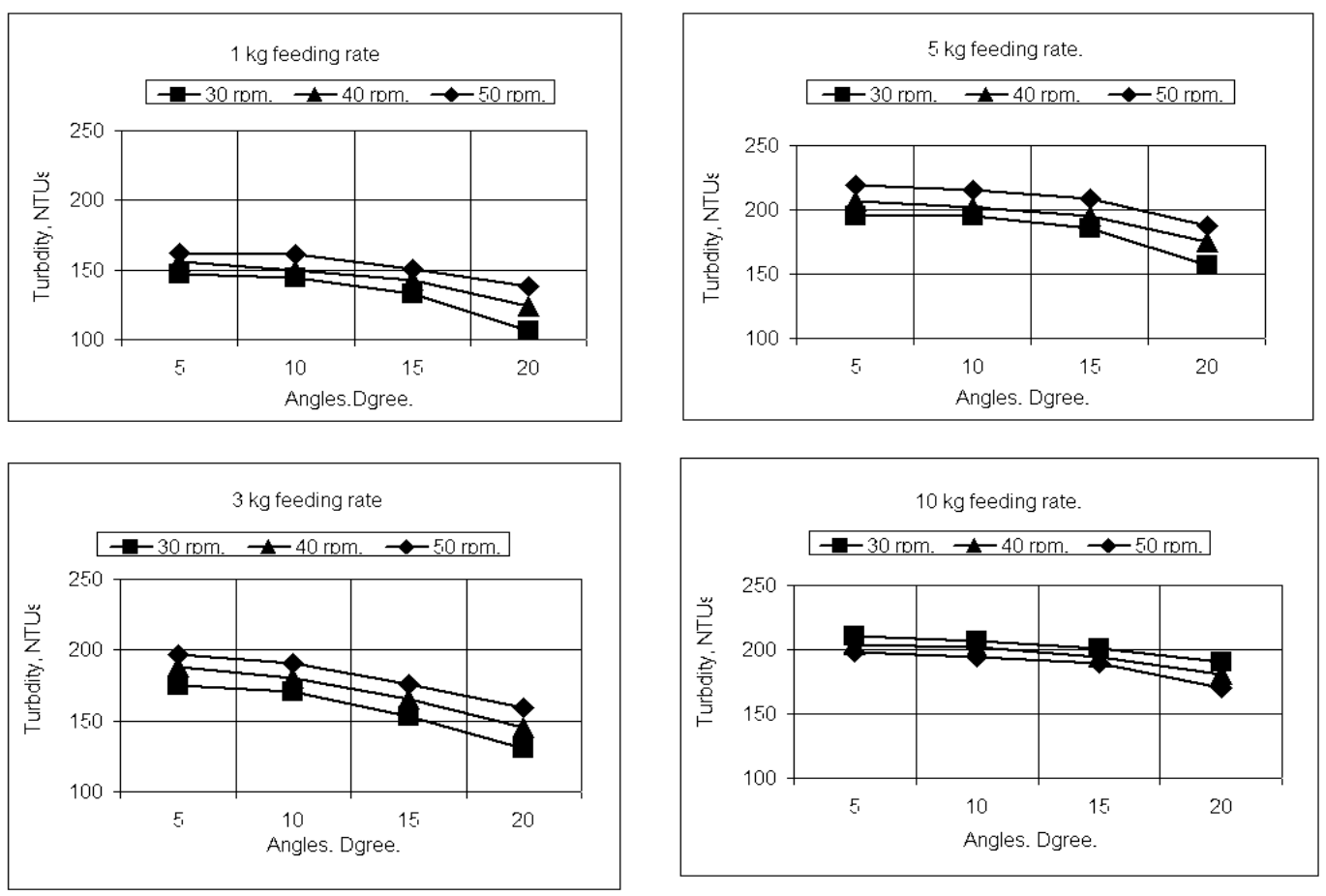

Fig. 6: Effect of brush speeds on water turbidity of Navel orange at different feeding rates and different angles.
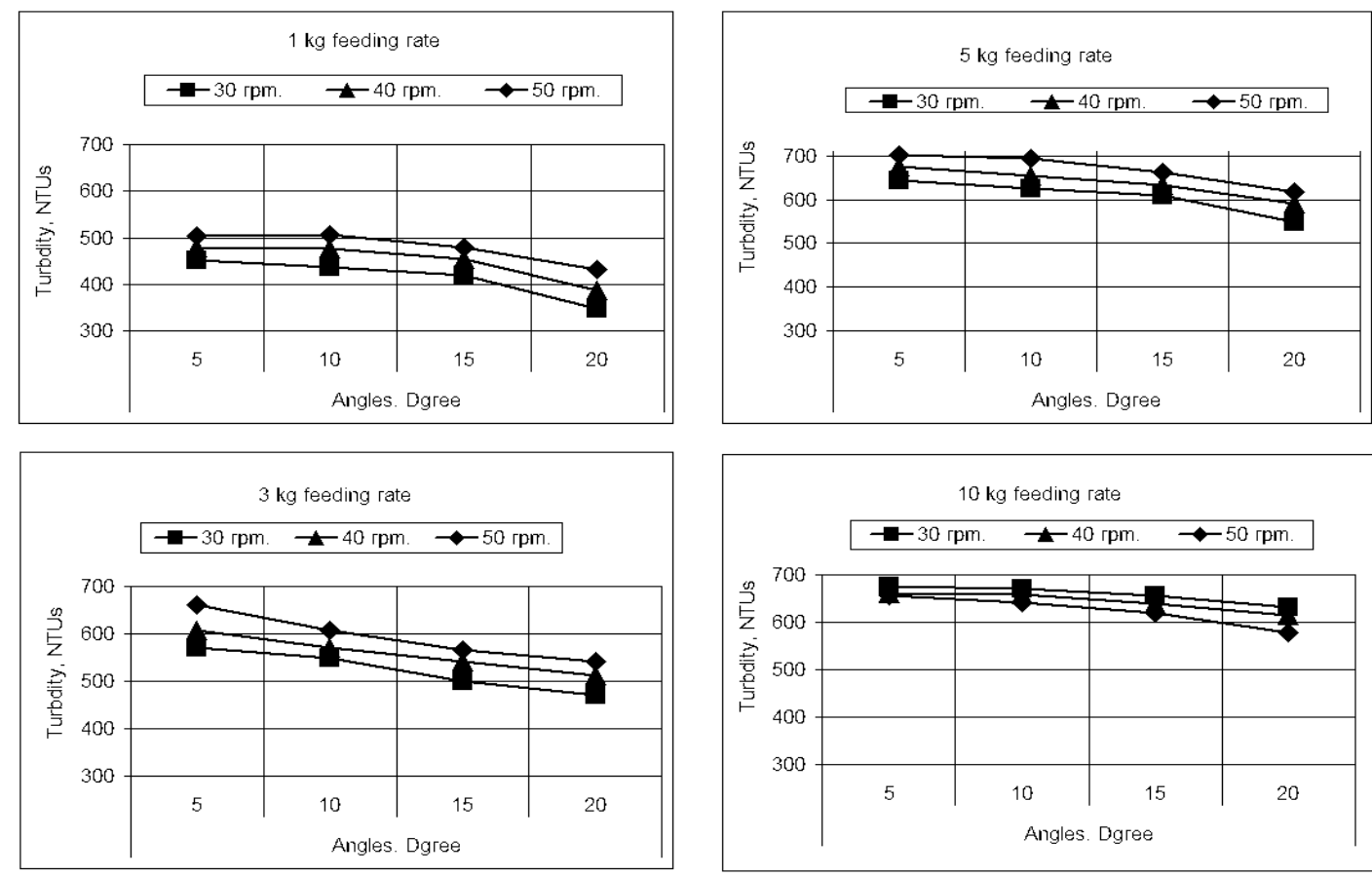

Fig. 7: Effect of brush speeds on water turbidity of Nicola potatoes at different feeding rates and different angles.

Misr J. Ag. Eng., April 2010 


\section{PROCESS ENGINEERING}
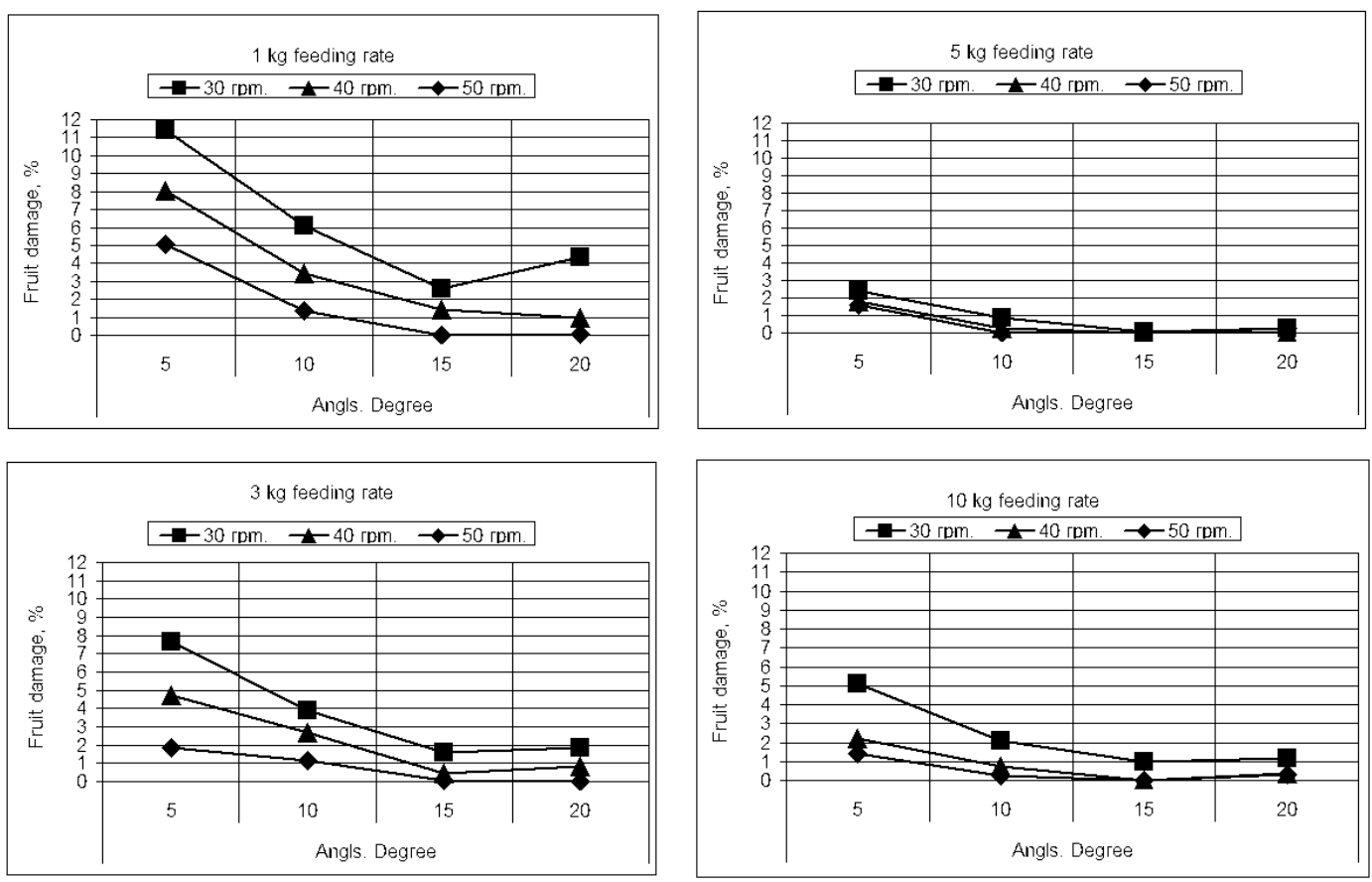

Fig. 8: Effect of brush speeds on Fruit damage of Navel orange at different feeding rates and different angles.
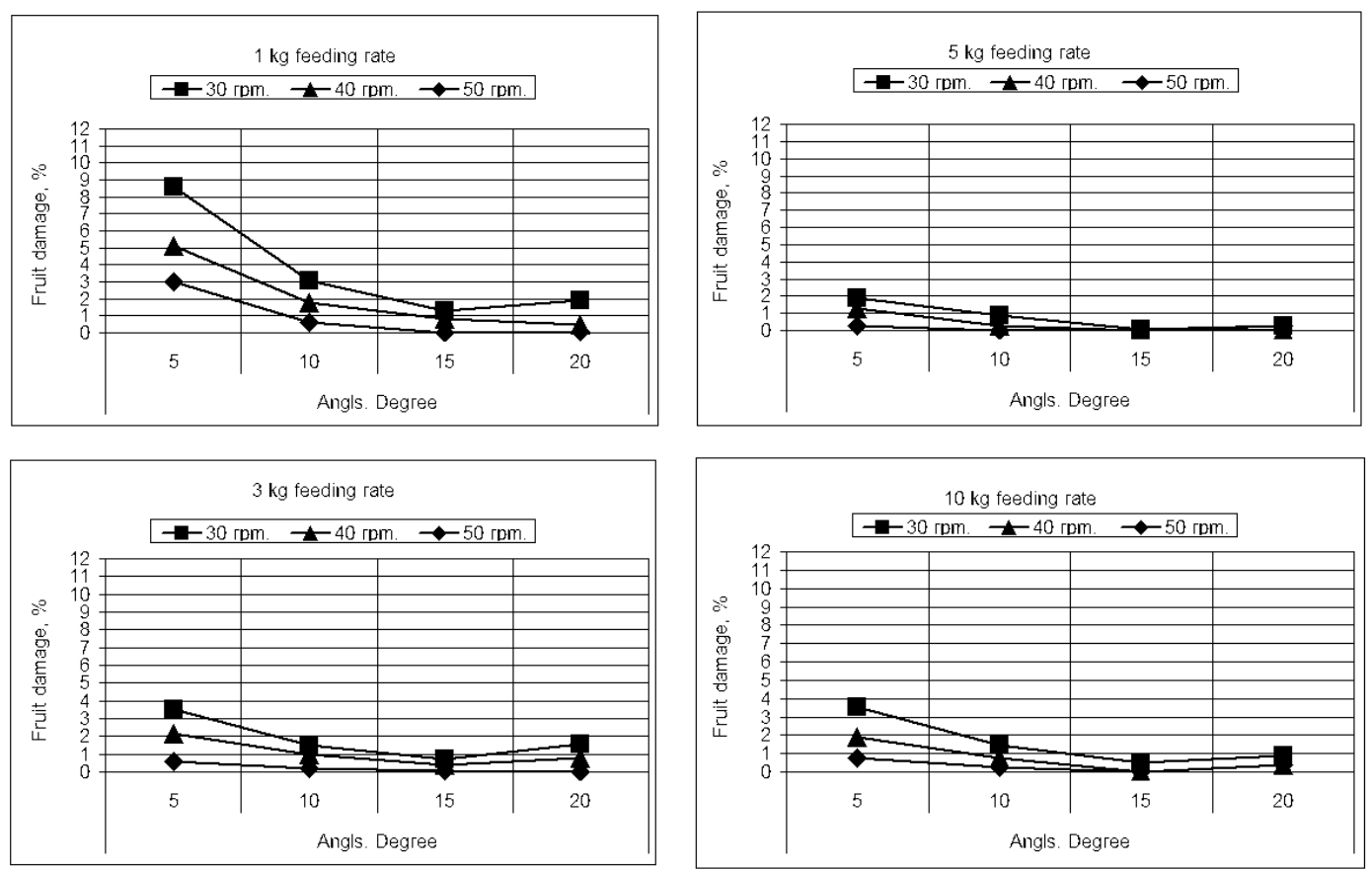

Fig. 9: Effect of brush speeds on Fruit damage of Nicola potatoes at different feeding rates and different angles.

Misr J. Ag. Eng., April 2010 


\section{CONCLUSIONS}

The obtained results of this study could be concluded that ability to using a turbidity as indicate quality of some vegetables and fruits that be washed in the washing machine.

\section{REFERENCES}

\section{A.A. Papadopoulou, A.A. Mouza, S.V. Paras and A.J. Karabelas.} 1998. A new turbidity meter for monitoring the quality of water. Intern. Conference "Protection \& Restoration of the Environment IV", 1-4 July, Sani, Halkidiki, Greece.

Abd El Rahman M.M. 1999. Engineering handling of some vegetable and fruits. Ph. D. thesis, Agric. Fac. of Agric., Mansoura Univ., A. R. E.

Chen, P. and Z. Sun. 1991. A review of non-destructive method for quality evaluation and sorting of agricultural products. J. Ag. Eng., 1 (49):85-98.

Davies, Jan and Robert Lambert. 2002. Engineering in Emergencies: A Practical Guide for Relief Workers, 2nd Edition. Warwickshire, UK: RedR / ITDG Publishing.

Hassan, A. A. 1988. A series of science and practice of agricultural crops - tomatoes - $1^{\text {st }}$ Ed, Arab House for Publishing and Distribution, p. 654.

Hussein, A.; A. Karam, M. Bahgat. 1991. Trading technology of horticultural crops after harvest, the Conference of Post-harvest handling of agricultural, Cairo from 16th $-21^{\text {st }}$ of December, A.R.E.

Kader, A. A. 1992. Postharvest Technology of Horticultural Crops. Pub. 3311 California Univ. Division of Ag. and Natural Res. 600 p.

Lawler, D.M. 1995. Turbidimetry and Nephelometry. Encyclopedia of Analytical Science, (s. ed. P. Worsfold), Academic Press Ltd, UK.

Scott, J. M.; D. J. Dunsmore and M. D. Keegan. 1981. Spray nozzle performance in cleaning food equipment. Trans. ASAE. 2 (3): 526536.

World Health Organization. (2004). Guidelines for Drinking-water Quality, 3rd Ed: Vol. 1. Recommendations. Geneva. 
Younis, S.M.; M.S. Omran; Y.F. Sharobeem and R.N. Thabet. 2005. Devlopment of washing machine for horticultural fruits. Misr J. Ag. Eng., 22 (2): 532-553.

\section{الملخص العربي \\ عكارة ماء الغسيل كمؤشر لكفاءة غسالة الخضار والفاكهة}

حسني سلطان القطري1

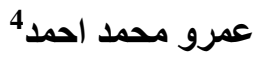

أجريت هذه الدراسة بهدف استغلال نسبة عكارة ماء الغسيل كمؤشر علي كفاءة غسيل الخضر الخراء

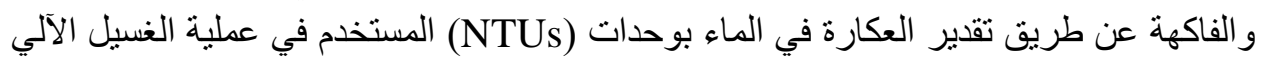

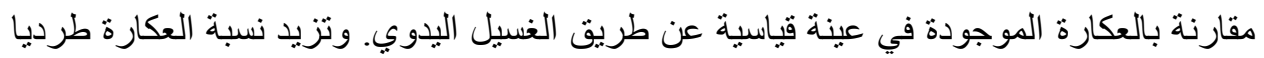

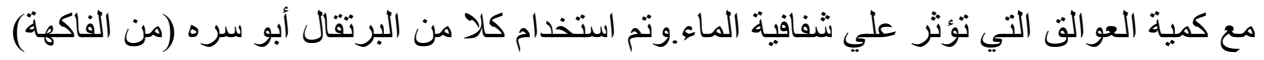
و البطاطس صنف نيقو لا (من الخضر ) في عملية الغسيل.

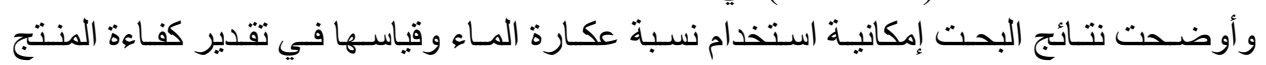
المغسول بو اسطة الغسيل الآلي.

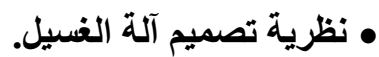

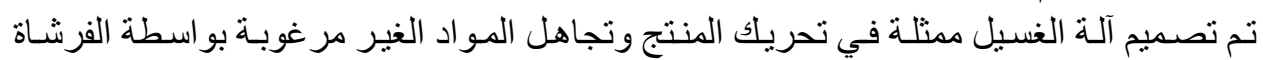

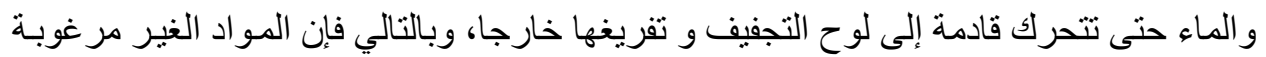

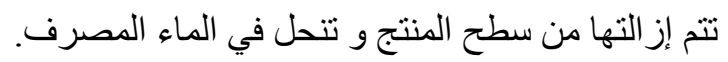

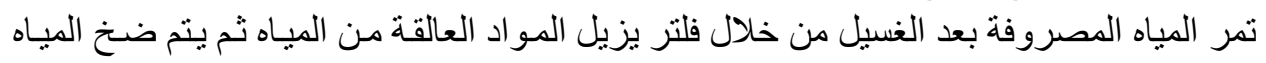

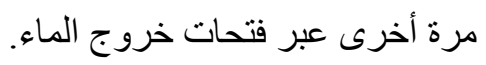
وكانت نتائج البحث ملخصة في النقاط التالية :

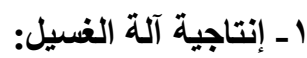

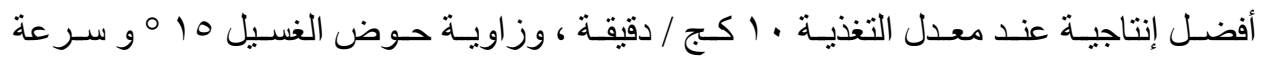

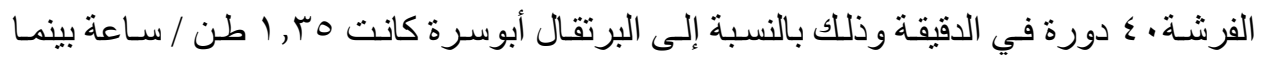

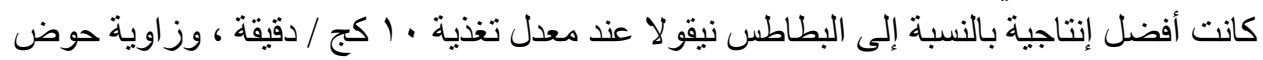

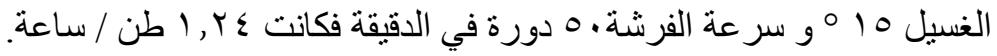

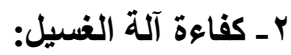

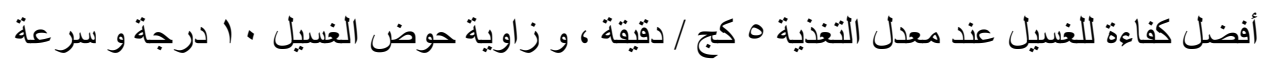

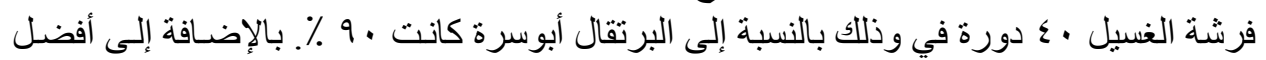

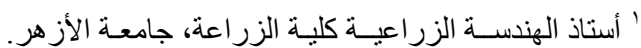

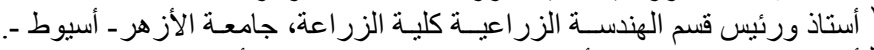

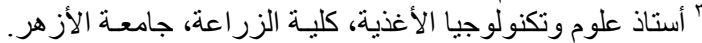

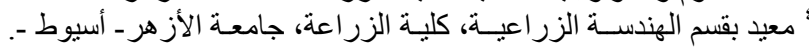




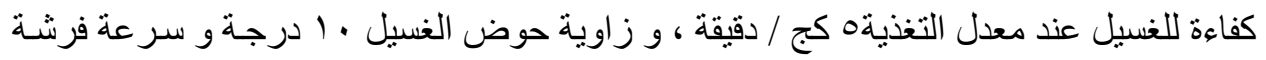

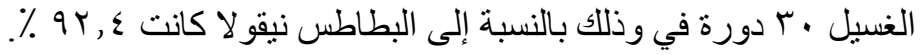

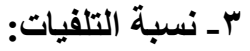

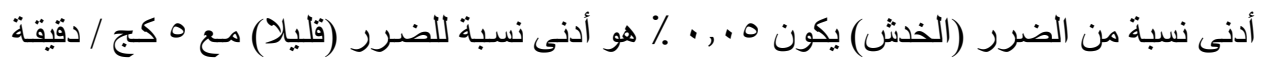

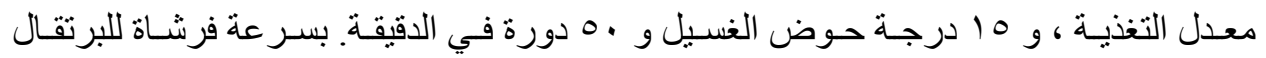

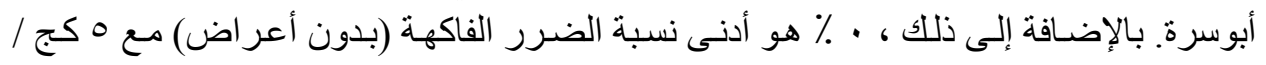

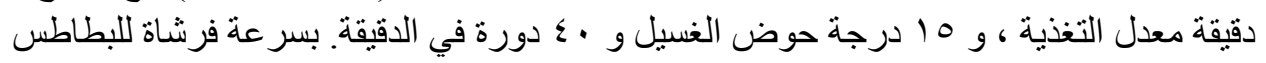

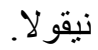

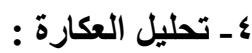

تحليل تعكر المياه يحدد الصلاحية لإعادة تدوير المياه واستخدامها مرة أخرى في عملية الغسيل.

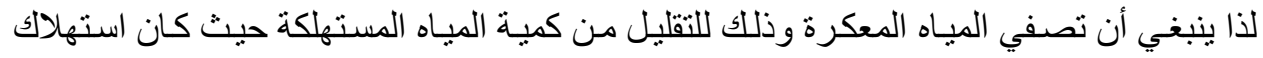

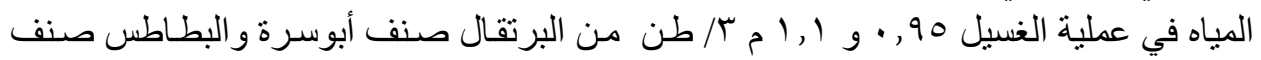

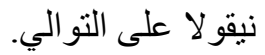

